JIIP: Jurnal IImiah IImu Pemerintahan

Volume 5, Nomor 1, Tahun 2020

DOI: 10.14710/jiip.v5i1.7085

\title{
Kandidasi Calon Anggota Legislatif Koruptor: Refleksi atas Pemilu 2019 di Malang
}

\author{
Hadityo Anugrah Allahi ${ }^{1}$, Fathur Rahman ${ }^{2}$ \\ 1,2 Program Studi Ilmu Pemerintahan, Universitas Brawijaya
}

Intisari

Tujuan dari penelitian ini mendeskripsikan proses kandidasi calon anggota legislatif koruptor dari Partai Demokrat dan Gerindra pada Pemilu 2019 di Kota Malang. Teori yang digunakan dalam penelitian ini adalah teori kandidasi, rekrutmen politik dan seleksi kandidat dari Austin Ranney. Metode penelitian yang digunakan adalah penelitian deskriptif kualitatif. Hasil penelitian menunjukkan bahwa terdapat dua calon legislatif (Caleg) dari Dapil Lowokwaru yang bernama Indra Tjahyono (ITJ) dan Teguh Puji Wahyono (TPW) dan kedua orang ini berstatus koruptor. Namun, kedua caleg ini masih terdaftar dalam Daftar Calon Tetap (DCT) yang dikeluarkan oleh Komisi Pemilihan Umum (KPU) Kota Malang. Pada saat pemungutan suara Pemilu 2019 kedua caleg koruptor masih terdaftar di surat suara Pemilu sedangkan caleg koruptor dari partai yang lain diganti oleh caleg yang baru. Kemudian dalam proses kandidasi yang dilakukan oleh kedua partai politik tersebut telah membuka pendaftaran bacaleg dari masyarakat umum atau dari eksternal partai tersebut. Hal yang kontras ditemukan, kedua partai politik ini tetap mengusung caleg koruptor dalam Pemilu 2019 karena mempertimbangkan aspek loyalitas terhadap partai politik pengusung.

\section{Kata Kunci}

kandidasi; caleg koruptor; Partai Demokrat; Partai Gerindra; pemilu

\section{Pendahuluan}

artai politik merupakan sarana bagi warga negara untuk berperan aktif dan menjadi wadah untuk berpartisipasi dalam proses pengelolaan negara. Sebagai lembaga politik, partai politik bukan merupakan sesuatu yang muncul dengan sendirinya. Kelahirannya mempunyai sejarah yang cukup panjang meskipun belum bisa dikatakan cukup tua juga. Bisa dikatakan bahwa kemunculan partai politik merupakan organisasi yang baru dalam kehidupan manusia. Sebagaimana seperti yang telah peneliti pahami bahwa partai politik merupakan wadah organisasi yang penting bagi suatu negara, terutama bagi negara yang menganut sistem demokrasi dimana bertujuan untuk menyalurkan aspirasi masyarakat dalam penyusunan dan pembuatan kebijakan publik (Ardianto, 2019). Selain itu, partai politik juga dapat digunakan sebagai alat atau 
kendaraan untuk mempersiapkan kader-kader terpilih agar dapat menduduki kursi-kursi kepemimpinan. Dalam proses menyiapkan calon-calon berkualitas, maka setiap kader partai harus melewati tahapan kaderisasi.

Kaderisasi merupakan proses yang penting bagi partai politik karena setiap partai harus mempersiapkan dan membina para kader-kadernya untuk menjadi anggota partai yang memiliki jiwa kepemimpinan dan kecakapan dalam berorganisasi yang optimal. Kaderisasi partai politik dilakukan dalam suatu sistem yang saling berhubungan antara satu dengan yang lainnya, yang terdiri atas perencanaan, pelaksanaan, dan evaluasi kaderisasi. Praktik kaderisasi partai politik di Indonesia bisa dikatakan masih jauh dari harapan. Hal ini dikarenakan oleh masih banyaknya kader-kader partai politik yang lahir secara instan. Munculnya kader partai secara instan inilah yang membuat bobroknya parlemen dan di pemerintahan. Matinya kaderisasi dalam partai politik ini salah satunya disebabkan karena partai politik tidak mempunyai ideologi dan visi yang jelas. Selain itu, partai politik telah menjadi bunker bagi para koruptor (Haboddin \& Rahman, 2013). Maka dari itu sangat sulit untuk mencari anggota yang dapat direkrut untuk menjadi kader partai.

Keberadaan Pemilihan Umum (Pemilu) diakui oleh negara penganut asas kedaulatan rakyat, dan diadakan pada semua jenis tataran politik baik sistem demokrasi, otoriter maupun totaliter. Dalam beberapa negara demokrasi, pemilu dianggap sebagai lambang dan juga tolak ukur dari sistem demokrasi (Budiardjo, 2003). Pemilu yang dilaksanakan di Indonesia merupakan sarana untuk membentuk pemerintahan yang demokratis melalui mekanisme yang jujur dan adil (Zazili, 2016). Dalam Pasal 28 huruf D Undang-Undang Dasar Negara Republik Indonesia 1945 (UUD NKRI Tahun 1945) menyebutkan bahwa "Setiap orang berhak memperoleh kesempatan yang sama dalam pemerintahan". Berdasarkan bunyi pasal tersebut, dalam hal pemilu, hak politik warga negara dalam pemilihan umum termasuk pemilihan kepala daerah, yakni hak untuk memilih dan dipilih merupakan suatu hak asasi yang dijamin dalam UUD Tahun 1945.

Namun di sisi yang lain, Komisi Pemilihan Umum (KPU) Republik Indonesia telah menetapkan Peraturan KPU (PKPU) Nomor 20 Tahun 2018 tentang Pencalonan Anggota Dewan Perwakila Rakyat (DPR), DPRD Provinsi, dan DPRD Kabupaten atau Kota sebagai pedoman dalam melaksanakan pencalonan Anggota DPR, DPRD Provinsi, DPRD Kabupaten, DPRD Kota dalam Pemilu 2019. Dalam aturan ini, ada pelarangan bagi mantan narapidana korupsi untuk mendaftarkan diri sebagai anggota legislatif. Dengan ditetapkannya PKPU tersebut maka pelarangan mantan narapidana korupsi mendaftarkan diri sebagai anggota legislatif sudah bisa diimplementasikan sejak masa pendaftaran calon anggota legislatif (caleg) di KPU.

Di KPU Kota Malang, pada Pemilu 2019 ternyata masih terdapat dua orang calon anggota legislatif tersangka korupsi terdaftar dalam DCT. Dua orang tersebut berasal dari partai politik, yaitu Partai Demokrat dan Partai Gerindra yang mencalonkan kader tersangka korupsi pada Pemilu 2019 yang lalu. Partai Demokrat mengusung calon incumbent, yakni Indra Tjahyono (selanjutnya ITJ). Pada pemilu 2014, ITJ berhasil 
memperoleh suara tertinggi di Dapil 4 Kota Malang yakni Kecamatan Lowokwaru dengan perolehan jumlah suara sah sebanyak 2.418 suara. Sementara dari Partai Gerindra, partai politik ini juga mencalonkan calon anggota legislatif incumbent, namanya, Teguh Puji Wahyono (selanjutnya TPW). Caleg Partai Gerindra pada pemilu legislatif DPRD Kota Malang ini juga merupakan calon anggota legisatif dengan perolehan suara terbanyak pada pemilu tahun 2014 di Daerah Pemilihan (Dapil) 4 Kota Malang yaitu Kecamatan Lowokwaru dengan perolehan 2.156 suara sah. Dapat dilihat bahwa kedua calon yang diusung oleh masing-masing partai merupakan calon yang sama-sama memiliki perolehan suara tertinggi di Dapil 4 Kota Malang yaitu Kecamatan Lowokwaru pada pemilu 2014.

Pada Pemilu 2019 ini, kedua calon incumbent tersebut kembali mencalonkan diri sebagai anggota legislatif DPRD Kota Malang. Kedua calon ini telah terdaftar dalam Daftar Calon Tetap (DCT) yang dikeluarkan oleh KPU pada tanggal 20 September 2018 (KPU Kota Malang, 2018). Namun pada pemilu kali ini, status kedua calon anggota legislatif tersebut adalah tersangka dalam kasus tindak pidana korupsi. Hal ini sangat menarik untuk dicermati mengingat status kedua orang tersebut adalah tersangka dan kedua calon ini merupakan calon yang diusung oleh partai politik. Selain itu, dapat dilihat bahwa proses kandidasi calon anggota legislatif yang dilakukan oleh partai-partai politik masih belum mampu untuk mengorbitkan calon legislatif yang berintegritas, baik dari jalur eksternal maupun jalur internal partai itu sendiri.

Masih diusungnya calon anggota legislatif tersangka korupsi pada Pemilu 2019 ini juga menimbulkan empat analisis yaitu pertama, kedua calon ini memang dianggap layak oleh partai politik pengusung untuk dicalonkan atau dikandidasikan dalam kontestasi Pemilu 2019 dan kedua, pencalonan tersebut memang didasari oleh ambisi yang sangat besar karena mereka masih memiliki keinginan untuk menjadi wakil rakyat atau menduduki jabatan publik yang ada di Kota Malang. Ketiga, terjadi kemandegan dalam proses pengkaderan sehingga kenapa yang dicalonkan hanya orang-orang itu saja bahkan cacat integritas. Keempat, buruknya pelembagaan dalam sebuah partai politik di tingkat lokal.

Artikel ini terangkai melalui wawancara dengan para pengurus partai yang menjadi caleg Demokrat dan Gerindra, Ketua KPPS Kelurahan Tasikmadu dan Koordinator Malang Corruption Watch (MCW) Malang. Selain itu, dokumen-dokumen seperti peraturan yang berkaitan pemilu, Peraturan KPU (PKPU). Kemudian data yang sudah diperoleh, dianalisis secara mendalam, selanjutnya dihasilkan kesimpulan yang menjelaskan kandidasi anggota legislatif koruptor di Kota Malang.

\section{Kandidasi dalam Partai Politik: Sebuah Pengantar Kajian}

Dalam hal kandidasi di sebuah partai politik terdapat satu konsep yang telah menjadi konsep dasar dari model kandidasi yang demokratis, yang disebut konsep demokrasi intra partai. Praktik yang ideal adalah partai politik dapat 
mengimplementasikan demokrasi di internalnya sendiri. Demokrasi intra partai menggambarkan pola relasi kuasa yang setara diantara yang ada dalam suatu partai politik. Demokrasi intra partai menurut Croissant dan Chambers dapat dikatakan sebagai sebuah karakter distribusi atas kekuasaan dalam proses pembuatan keputusan antara anggota dan pemimpin di dalam sebuah politik yang didasarkan pada prinsip inklusivitas dan desentralisasi (Chambers \& Croissant, 2008).

Kemudian, persoalan kandidasi menjadi kajian penting dalam penelitian ini. Karena untuk menjawab persoalan tersebut, maka Rahat dan Hazan menawarkan penjelasan tentang kandidasi dengan menggunakan empat dimensi, diantaranya dimensi kandidasi (inklusif/eksklusif), dimensi pemilih kandidat, dimensi desentralisasi, dan dimensi voting atau penunjukan. Empat dimensi tersebut digunakan oleh Rahat sebagai cara untuk membangun cross-case studies (Rahat, 2009).

Sementara itu, Krister Lundell berargumen bahwa dalam penentuan dimensi pemilihan kandidat dan sistem voting atau penunjukan merupakan hal yang saling bersinggungan serta sistem voting dianggap lebih inklusif dibandingkan dengan sistem penunjukan. Argumentasi yang dibangun oleh Lundell ini merupakan dimensi yang lebih fokus pada dimensi desentralisasi dalam melihat kandidasi yang berlangsung di Eropa Timur dan Eropa Selatan (Lundell, 2004).

\section{Tingkatan rekrutmen calon kandidat pada Pemilu}

Disisi lain, muncul juga pemikiran dari Pipa Norris yang menyatakan bahwa rekrutmen politik bukan hanya persoalan tentang pencalonan perwakilan yang dipilih pada tingkat lokal, regional, nasional, dan sub-nasional, melainkan juga tentang penunjukan jabatan publik. Partai politik memiliki peran penting dalam memilih calon anggota legislatif. Setiap negara pastinya menentukan beberapa syarat bagi pihak yang dirasa mampu untuk mendapatkan jabatan legislator.

Dalam artikel yang telah ditulis oleh Pippa Norris (Katz \& Crotty, 2006) bahwa ada tiga tingkatan dalam proses rekrutmen calon kandidat, yakni sertifikasi, pencalonan, dan pemilihan. Pertama, proses sertifikasi (certification), yaitu mengenai siapa yang layak untuk dipilih menjadi calon anggota legislatif. Syarat-syarat formal yang harus dipenuhi para kandidat diadakan berdasarkan undang-undang pemilu. Persyaratannya adalah seperti umur, kewarganegaraan, rekam jejak, tempat kediaman, moralitas, inkompatibilitas, popularitas, simpanan keuangan, pengalaman berpolitik, dan keharusan untuk mengumpulkan tandatangan dukungan.

Kedua, proses pencalonan (nomination), ialah mengenai siapa yang memutuskan kandidat yang akan dicalonkan sebagai anggota legislatif. Untuk mengukur tingkat demokrasi dalam internal partai dapat dilihat dari beberapa hal, seperti: (a). Tingkat pemusatan, yaitu seberapa jauh pencalonan ditetapkan oleh kepemimpinan partai nasional atau diserahkan ke bawah kepada daerah setempat. (b). Keluasan dari mengambil bagian, yaitu mengenai apakah hanya beberapa orang yang memilih calon atau apakah banyak orang terlibat dalam proses ini. dan (c). Ruang lingkup pembuatan 
keputusan, yaitu mengenai apakah ada pilihan dari satu, beberapa, atau bermacammacam pendapat berlomba-lomba untuk pencalonan tersebut.

Ketiga, proses pemilihan (election), yaitu mengenai siapa yang terpilih sebagai hasil dari proses pencalonan. Tipe calon yang dipilih oleh partai mempunyai kapasitas untuk mempengaruhi kualitas dari anggota legislator, dan juga susunan dari pemerintahan. Sebagai contoh, untuk memiliki pengaruh untuk lembaga legislatif, pembuatan kebijakan, dan penyelidikan tentang hasil pemilu, jika partai memutuskan untuk memilih pengacara profesional, atau aktivis lokal, selebriti, atau pegawai partai berpengalaman (Katz \& Crotty, 2006).

\section{Proses seleksi kandidat Partai Politik pada Pemilu}

Studi yang berkaitan dengan rekrutmen politik juga memfokuskan perhatian pada hal penting seperti mengenai proses seleksi kandidat. Seleksi kandidat adalah metode yang digunakan partai politik dalam memilih calon yang akan duduk di berbagai sektor kekuasaan, dalam proses hasil pemilihan. Beberapa kandidat tersebut kemudian dipilih satu diantara mereka. Karena biasanya setiap partai menyeleksi hanya satu kandidat, atau menurut sistem perbandingan dari daftar pilihan partai. Penyeleksian kandidat merupakan satu dari hal yang harus dilakukan dalam sebuah partai politik dan parlemen. Kondisi ini untuk waktu yang panjang hingga batas waktu tersebut berakhir.

Menurut Austin Ranney, seleksi kandidat adalah proses utama resmi yang dimiliki oleh sebuah partai untuk memutuskan seseorang yang secara resmi dipilih untuk memegang sebuah jabatan yang ditandai oleh suara pemilih dalam komunikasi pemilihan sebagai rekomendasi dan kandidat yang didukung atau dari daftar kandidat. Proses seleksi tersebut terbatas pada partai politik saja, untuk menentukan calon yang bakal dinominasikan dalam pemilu (Katz \& Crotty, 2006).

Dalam proses seleksi kandidat ada empat hal yang paling penting untuk diperhatikan (Rahat, 2009). Keempat hal itu adalah: Pertama, Siapa aktor yang ikut serta dalam proses seleksi (candidacy) ? Candidacy menjelaskan tentang siapa yang dapat dicalonkan atau ditetapkan sebagai kandidat dari sebuah partai. Proses ini dikualifikasikan dalam dua tingkat yaitu inklusifitas, dan eksklusifitas. Dalam inklusifitas, setiap orang dapat mencalonkan diri menjadi kandidat dalam partai, tidak hanya terbatas pada anggota partai ataupun pengurus partai saja, namun terbuka bagi semua warga negara. Sementara dalam eksklusifitas ada beberapa kondisi yang membatasi dan menutup ruang hak seseorang maupun anggota kader partai untuk dapat ikut serta dalam seleksi kandidat itu dilaksanakan, sehingga pola rekrutmen ini bersifat tertutup dan tidak demokratis.

Kedua, Siapa yang menjadi penyeleksi (selectorate)? Proses ini terkait tentang sebuah lembaga partai yang dibentuk dalam menyeleksi kandidat. Lembaga tersebut berkaitan dengan berapa banyak orang yang terlibat dalam menentukan proses seleksi. Terdiri dari anggota internal partai tertentu atau melibatkan warga negara secara luas. Ketika warga negara dilibatkan dalam proses seleksi kandidat maka pola tersebut dapat 
diklasifikasikan sebagai model seleksi inklusif. Sebaliknya, seleksi eksklusif yaitu ketika seleksi kandidat ditentukan oleh pimpinan oleh pimpinan atau elit partai saja. Lebih rinci hal ini bertautan dengan seberapa besar peran pimpinan partai menentukan hasil seseorang dalam proses pencalonan. apakah ditentukan oleh pimpinan pusat ataukah sebagian didistribusikan kepada pimpinan regional lokal.

Ketiga, Dimana proses seleksi dilakukan (derajat desentralisasi)? Proses ini menjelaskan persoalan dimana lingkup pengambilan keputusan terkait persoalan derajat desentralisasi dan sentralistik. Ketika kandidat diseleksi secara eksklusif oleh penyeleksi pada tataran pusat (nasional) maka metode ini disebut derajat sentralistik. Sebaliknya ketika seleksi kandidat dilakukan oleh penyeleksi partai pada tataran lokal dan berlangsung secara otonom maka disebut dengan metode desentralisasi.

Keempat, Bagaimana kandidat dinominasikan oleh partai (voting atau penunjukan)? Dalam hal ini terdapat dua model penominasian. Pertama, model sistem pemilihan (voting) yaitu penominasian berdasarkan suara dimana semua kandidat diseleksi melalui prosedur pemilihan tanpa seorang penyeleksi pun dapat mengubah daftar komposisi. Kedua, model sistem penunjukan dimana penentuan calon ditunjuk tanpa menggunakan prosedur pemilihan, calon diangkat tanpa mebutuhkan persetujuan yang lain kecuali oleh partai atau pemimpin partai (Hidayat, 2012).

\section{Konteks Calon Anggota Legislatif Koruptor di Malang}

Kasus korupsi yang menjerat anggota DPRD Kota Malang berawal pada tahun 2017. Lebih tepatnya pada tanggal 9 Agustus 2017 yang membahas mengenai kasus suap pembahasan Anggaran Pendapatan dan Belanja (APBD) Perubahan Kota Malang Tahun Anggaran 2015. Kasus ini mulai mencuat setelah Komisi Pemberantasan Korupsi (KPK) Republik Indonesia melakukan penggeledahan di Kota Malang dan modus yang digunakan adalah uang pelicin untuk pembahasan APBD Perubahan Tahun Anggaran 2015. Kasus korupsi ini telah menjerat Abah Anton yang merupakan Walikota Malang periode tahun 2013-2018. Dalam pengembangan kasusnya, pada 11 Agustus 2017 Ketua DPRD Kota Malang yaitu M. Arief Wicaksono ditetapkan sebagai tersangka. M. Arief Wicaksono disangkakan telah menerima suap dari Kepala Dinas Pekerjaan Umum dan Perumahan Kota Malang tahun 2015 sebesar Rp. 700 juta. Dalam kasus ini, terdapat 18 anggota dewan lain yang ikut terseret, yaitu Sulik Lestyowati, Abdul Hakim, Bambang Sumarto, Imam Fauzi, Syaiful Rusdi, Tri Yudiani, Suprapto, Mohan Katelu, Salamet, M. Zaenudin, Wiwik Hendri Astuti, heri Puji Utami, Abd. Rachman, Hery Subiantono, Rahayu Sugiharti, Sukarno, dan Ya'qud Ananda Gudban (Fadhil, 2018) .

Pada saat kasus ini tengah berjalan, KPK ternyata juga menemukan kasus baru yang muncul dalam fakta persidangan. KPK kembali turun dan melakukan penggeledahan serta penyelidikan di Kota Malang. Kasus baru yang uncul adalah kasus Gratifikasi dalam APBD Tahun Anggaran 2015 senilai Rp. 5,8 miliar dan pengadaan lahan sampah TPA Supit Urang senilai Rp. 300 juta. Pada tanggal 3 September 2018 KPK kembali menetapkan beberapa tersangka dalam kasus ini. Sebanyak 22 anggota DPRD 
Kota Malang ditetapkan sebagai tersangka oleh KPK dalam kasus korupsi ini. Ke-22 anggota DPRD Kota Malang tersebut diantaranya adalah Arief Hermanto, Teguh Mulyono, Mulyanto, Choeroel Anwar, Suparno Hadiwibowo, Imam Ghozali, Mohammad Fadli, Asia Iriani, Indra Tjahyono, Een Ambarsari, dan Bambang Triyoso. Selain itu juga terdapat nama Diana Yanti, Sugiarto, Afdhal Fauza, Syamsul Fajrih, Hadi Susanto, Erni Farida, Sony Yudiarto, Harun Prasojo, Teguh Puji Wahyono, Choirul Amri, dan Ribut Harianto (Setyawan, 2018).

Pasca korupsi massal yang dilakukan oleh DPRD Kota Malang dalam jangka waktu sekitar 3 tahun, mulai tahun 2015 sampai tahun 2018 membuat DPRD melakukan langkah cepat guna mengisi kekosongan struktur keanggotaan DPRD. Langkah awal yang dilakukan ialah dengan melakukan Pergantian Antar Waktu (PAW). Langkah ini diambil oleh masing-masing fraksi yang ada di DPRD Kota Malang. Setelah setiap fraksi mengambil tindakan terhadap anggota DPRD yang terjerat kasus korupsi pada akhirnya terbentuklah susunan baru keanggotaan DPRD Kota Malang dan 40 anggota baru tersebut dilantik pada 10 September 2018.

Setelah masa jabatan anggota DPRD Kota Malang periode 2014-2019 telah berakhir, maka diadakanlah Pemilu Legislatif tahun 2019. Dalam pemilu kali ini, terdapat dua orang dari 12 mantan anggota DPRD Kota Malang yang berstatus tersangka korupsi tetapi namanya masih terdaftar dalam DCT yang dikeluarkan oleh KPU kota Malang. Daftar Calon Tetap (DCT) tersebut dikeluarkan oleh KPU Kota Malang pada 20 September tahun 2018.

Dalam pencalonan calon anggota legislatif koruptor, tidak ada peraturan atau undang-undang yang mengatur mengenai mantan narapidana koruptor dilarang untuk mencalonkan diri dalam pemilihan kepala daerah maupun pemilihan anggota legislatif. Ada beberapa kriteria mengenai seseorang yang terbukti melakukan tindak pidana tidak boleh untuk mengikuti proses-proses politik, seperti pertama, seseorang yang sedang dalam masa pidana. Kedua, mendapatkan pidana tambahan berupa pencabutan hak politik. Tetapi, ketika putusan itu sudah dijalani dengan masa tertentu, mantan narapidana tersebut boleh mencalonkan diri kembali sebagai calon legislatif, calon kepala daerah, maupun calon presiden. Hal ini sesuai dengan putusan Mahkamah Konstitusi (MK) Republik Indonesia Nomor 56/PUU-XVII yang tentang pelarangan mantan narapidana korupsi ikut dalam kandidasi dalam pemilihan umum. Di sisi lain, negara bisa melakukan pembatasan untuk Hak Asasi Manusia (HAM), salah satunya adalah pembatasan mengenai hak politik. Hal ini dapat dilakukan, mengingat seseorang yang telah melakukan tindak pidana korupsi tersebut dianggap telah melakukan pengkhianatan terhadap jabatan, dan telah mengkhianati rakyat terhadap amanat yang telah diberikan oleh rakyat (wawancara penulis, 27 November 2019). Maka sebagai bentuk hukuman, seorang mantan narapidana korupsi tidak diberi ruang untuk mencalonkan diri sebagai kepala daerah, anggota legislatif, dan lembaga-lembaga eksekutif lainnya. 


\section{Kandidasi Caleg DPRD Partai Demokrat dan Gerindra}

Dalam penelitian ini, Partai Demokrat mengusung calon incumbent, yaitu Indra Tjahyono alias ITJ. Pada pemilu sebelumnya (Tahun 2014), ITJ berhasil memperoleh suara tertinggi di Daerah Pemilihan (Dapil) 4 Kota Malang yakni Kecamatan Lowokwaru dengan perolehan jumlah suara sah sebanyak 2.418 suara. Sementara dari Partai Gerindra, partai politik ini juga mencalonkan sebagai calon anggota legislatif incumbent pada pemilu tahun 2019 i. Calon yang diusung oleh Partai Gerindra ini bernama Teguh Puji Wahyono alias TPW. Caleg Partai Gerindra pada pemilu legislatif DPRD Kota Malang ini juga merupakan calon anggota legislatif dengan perolehan suara terbanyak pada pemilu tahun 2014 di Dapil 4 Kota Malang yaitu Kecamatan Lowokwaru dengan perolehan fantastis. Menurut Dwi Astutik, Bendahara Pengurus Dewan Pimpinan Dewan (DPD) Partai Gerindra, TPW selain menjadi Ketua Dewan Pimpinan Cabang (DPC) Lowokwaru juga termasuk anggota Tim seleksi caleg Pemilu 2019 di Kota Malang (wawancara penulis, 20 November 2019). Dapat kita lihat bahwa kedua calon yang diusung oleh masing-masing partai merupakan calon yang sama-sama memiliki perolehan suara tertinggi di Dapil 4 Kota Malang yaitu Kecamatan Lowokwaru pada pemilu periode sebelumnya, yaitu Pemilu tahun 2014.

Pada Pemilu tahun 2019 ini, kedua calon incumbent tersebut kembali mencalonkan diri sebagai anggota legislatif DPRD Kota Malang dan keduanya kembali mencalonkan diri melalui jalur partai politik. Nama Indra Tjahyono dan Teguh Puji Wahyono masih terdaftar dalam Daftar Calon Tetap yang dikeluarkan oleh KPU pada tanggal 20 September 2018. Indra Tjahyono maju dari Partai Demokrat sementara Teguh Puji Wahyono merupakan calon legislatif dari Partai Gerindra. Namun pada pemilu kali ini, status kedua calon anggota legislatif tersebut adalah tersangka dalam kasus tindak pidana korupsi. Patut untuk dicermati bersama bahwa seorang terpidana korupsi masih bisa mencalonkan diri sebagai calon anggota legislatif pada kontestasi pemilihan umum. Partai politik di indonesia memang penuh ironi. Partai politik mestinya menjadi pilar untuk tumbuh- kembangnya proses demokratisasi. Namun tetap saja, ada partai politik yang tetap mengusung tersangka korupsi. Dengan masih terdaftarnya dua calon anggota legislatif pada Daftar Calon Tetap tersebut mengindikasikan bahwa proses kaderisasi dan mekanisme pencalonan atau kandidasi patut dipertanyakan. Mekanisme kandidasi seperti apa yang dilakukan oleh partai-partai politik dalam menentukan calon anggota legislatif yang akan diusung oleh partai politik pengusung.

Temuan dari penelitian ini menunjukkan bahwa proses mekanisme kandidasi caleg dalam Partai Demokrat dilakukan secara terbuka, dimana melibatkan publik secara luas. Dalam proses awal, maka ada dua golongan yang dapat mendaftar sebagai caleg yaitu calon yang berasal dari internal partai atau eksternal partai. Bagi calon yang berasal dari eksternal harus menjadi anggota Partai Demokrat terlebih dahulu. Setelah itu, tahapan 
selanjutnya adalah pendaftaran dan verifikasi di tingkat Dewan Pimpinan Cabang (DPC) untuk Kabupaten atau Kota, sementara untuk DPRD Provinsi dilakukan pendaftaran dan verifikasi di Dewan Pimpinan Daerah (DPD).

Tahapan selanjutnya yaitu penetapan yang dilakukan oleh DPC untuk memperhatikan saran dan arahan dari Majelis Tinggi Cabang. Setelah tahapan tersebut selesai dilakukan, maka nama-nama caleg yang akan ditetapkan oleh DPC diusulkan ke Dewan Pimpinan Pusat (DPP) melalui DPD. Tahapan terakhir, pengesahan calon anggota legislatif oleh DPP dengan memperhatikan pertimbangan, saran dari Majelis Tinggi Partai. Setelah semua tahapan selesai maka DPC, DPD akan mendaftarkan nama caleg dalam Daftar Calon Sementara (DCS).

Meskipun secara normatif dipublikasikan secara masif ke publik namun yang harus dimonitor secara terbuka adalah pada tahap penetapan caleg oleh selektor atau penyeleksi. Karena pada tahap ini, publik tidak mengetahui peristiwa yang terjadi, perdebatan seperti apa yang keluar dalam internal partai, komunikati tawar-menawar dalam nomor urut, bahkan harga kursi. Oleh sebab itu, timbul analisis bahwa penetapan calon anggota legislatif oleh partai politik bersifat tertutup, oligarkis.

Mekanisme kandidasi calon legislatif DPRD Kota Malang dari Partai Gerindra pada umunya bersifat terbuka. Menurut hasil wawancara penulis dengan Bapak Dony Kurniawan selaku Wakil Sekretaris Partai Gerindra Kota Malang, penulis merumuskan bahwa proses kandidasi yang dilakukan oleh Partai Gerindra secara garis besarnya adalah untuk menjaring kader-kader terbaik dan berkualitas yang dimiliki oleh Partai Gerindra. Dalam mekanisme kandidasi yang dilakukan oleh Partai Gerindra, dilakukan beberapa tahapan, yaitu: (1) Rapat internal Pengurus Harian DPC Partai Gerindra Kota Malang; 2) Sosialisasi dan mekanisme pendaftaran Caleg DPRD; (3) Pendaftaran bakal caleg DPRD; (4) Seleksi bakal caleg DPRD Partai Gerindra. Semua rangkaian tersebut sepenuhnya menjadi kewenangan dari DPC.

Selanjutnya, berdasarkan temuan yang diperoleh di Kota Malang, mekanisme kandidasi yang telah dilakukan oleh lembaga penyelenggara pemilu terhadap seorang calon yang sedang dalam masa persidangan tidak serta-merta bisa dilakukan penggantian dan partai politik juga tidak bisa melakukan penggantian terhadap calon tersebut. Hal ini berbeda dengan calon yang sudah ditetapkan menjadi tersangka dan putusan dari Pengadilan Tindak Pidana Korupsi (Tipikor) tersebut sudah berkekuatan hukum tetap atau incracht. 
Bagan 1: Proses Kandidasi Caleg Koruptor DPRD Kota Malang

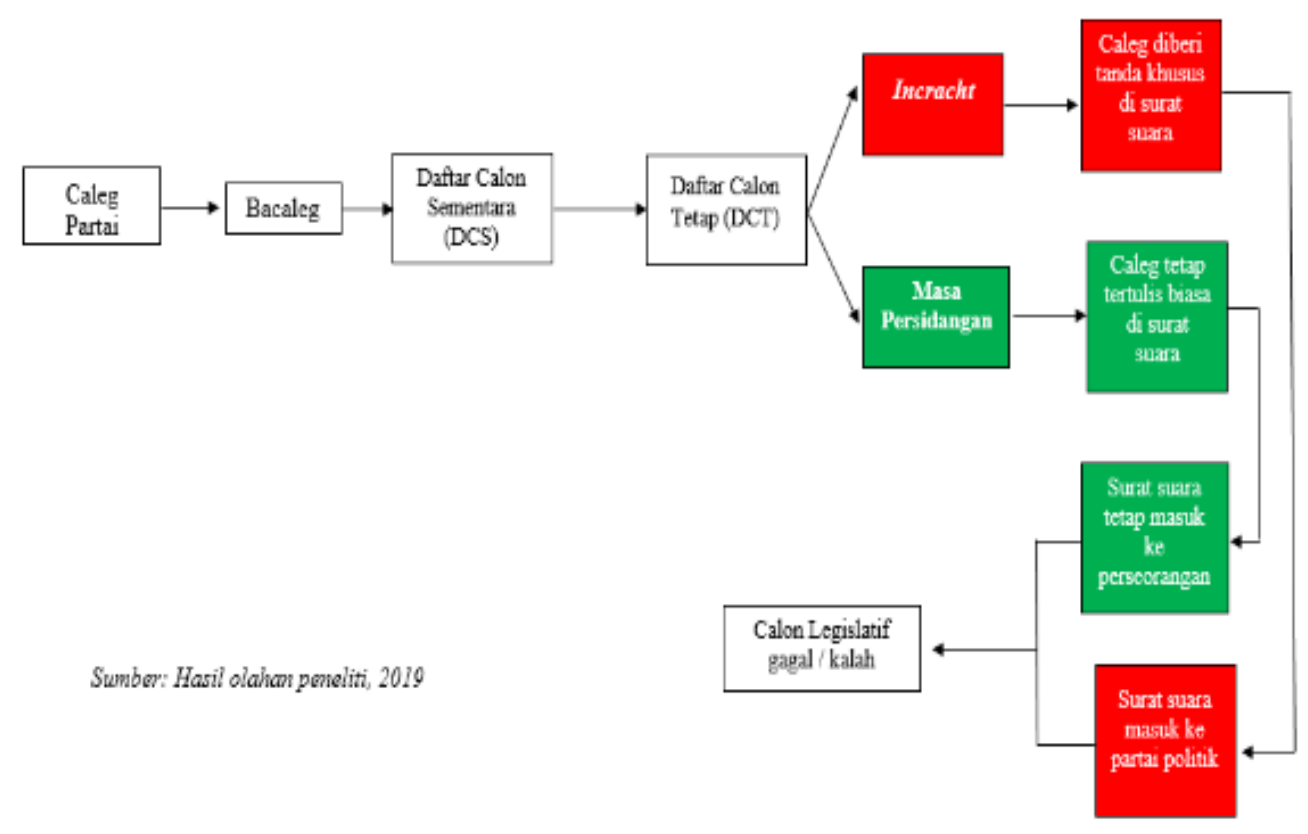

Dalam bagan di atas, dapat disimpulkan bahwa calon legislatif koruptor yang sudah memiliki putusan tetap atau incracht maupun calon anggota legislatif koruptor yang masih dalam proses persidangan, para calon anggota legislatif tersebut sama-sama tidak memiliki jumlah suara yang cukup untuk menjadi anggota parlemen lokal di Kota Malang. Meskipun para calon anggota legislatif tersebut diusulkan oleh partai politik pengusungnya masing-masing, namun hal itu tidak membuat para calon mendapatkan dukungan yang cukup dari masyarakat untuk menjadi anggota legislatif. Para calon anggota legislatif yang masih terdaftar dalam Daftar Calon Tetap atau DCT, tidak bisa diganti dengan usulan dari partai politik pengusungnya. Hal yang bisa dilakukan hanya dengan memberikan tanda khusus pada surat suara yang mencantumkan nama beserta foto dari calon legislatif tersebut dan diumumkan seperti yang sudah dilakukan oleh Maryadi, Ketua KPPS Pemilu 2019 di Malang pada saat perhitungan suara di TPS (wawancara penulis, 12 November 2019).

Proses kandidasi calon anggota legislatif yang dilakukan oleh para partai politik ternyata masih belum mampu untuk mengorbitkan calon-calon anggota legislatif yang berintegritas, baik dari jalur eksternal maupun jalur internal partai itu sendiri. Selain itu, masih diusungnya calon anggota legislatif tersangka korupsi pada Pemilu 2019 ini juga menimbulkan empat empat persepsi, yaitu: pertama, kedua calon ini memang dianggap layak oleh partai politik pengusung untuk dicalonkan atau dikandidasikan dalam kontestasi Pemilu 2019 dan kedua, pencalonan tersebut memang didasari oleh ambisi yang sangat besar karena mereka masih memiliki keinginan untuk menjadi wakil rakyat atau menduduki jabatan publik yang ada di Kota Malang. Ketiga, terjadi kemandegan dalam proses pengkaderan sehingga kenapa yang dicalonkan hanya orang-orang itu saja 
bahkan cacat integritas. Keempat, buruknya pelembagaan dalam sebuah partai politik di tingkat lokal. Karena itu, seusai dengan yang disampaikan Yuwanto (2018) bahwa diperlukan pembenahan dalam sistem kepartaian, parlemen, institusi politik dan keterlibatan masyarakat sipil dalam kandidasi anggota legislatif.

\section{Penutup}

Partai politik merupakan salah satu pilar penting dalam ranah demokrasi di Indonesia, bahkan dunia. Salah satu fungsi penting dan krusial yang dimiliki oleh partai politik adalah rekrutmen. Rekrutmen politik yang dilakukan partai-partai politik di Indonesia. Kandidasi merupakan titik pertarungan krusial bagi seorang politisi, bahkan seorang politisi dari kader partai sekalipun. Bagi seorang politisi yang merupakan kader partai, kandidasi menjadi jalur penting dan krusial yang harus mereka lewati. Keterampilan dan keahlian penting yang harus dimiliki oleh seorang calon legislatif adalah menguasai dan membentuk jaringan-jaringan diantara aktor-aktor yang ada dalam partai politik.

Pola kandidasi dan penentuan calon legislatif yang demokratis memang sangat perlu untuk dilakukan oleh pengurus partai-partai politik di lingkup internal partai. Dalam hal ini, peran masyarakat sipil juga perlu untuk dilibatkan dalam mendorong proses atau mekanisme kandidasi yang lebih demokratis. Dikemudian hari, maka masyarakat perlu didorong untuk melakukan ekspos serta pengawasan pada tahapan kandidasi ini sehingga nantinya peran masyarakat ini dapat membuka sisi gelap dari proses kandidasi yang selama ini masih menjadi rahasia bagi publik.

\section{Ucapan Terima Kasih}

Penulis mengucapkan terimakasih pada teman diskusiku yaitu Mas Inggito dan Mba Sekar sehingga tulisan ini terbentuk.

\section{Pendanaan}

Penulis tidak menerima bantuan pembiayaan untuk penelitian, kepenulisan (authorship), dan publikasi dari pihak manapun.

\section{Daftar Pustaka}

Ardianto, H. T. (2019). Uang dan partai politik: Urgensi mengatur keuangan parpol dan kandidat dalam kompetisi elektoral. JIIP: Jurnal IImiah IImu Pemerintahan; Vol 4, No 1 (2019)DO - 10.14710/jiip.v4i1.4733. Retrieved from https://ejournal2. undip.ac.id/index.php/jiip/article/view/4733

Budiardjo, M. (2003). Dasar-dasar ilmu politik: Gramedia pustaka utama.

Chambers, P., \& Croissant, A. (2008). Intra-party democracy in Thailand. Unpublished manuscript. 
Fadhil, H. (2018). 18 Anggota DPRD Kota Malang Tersangka Suap Segera Disidang. Retrieved from https://news.detik.com/berita/d-4129301/18-anggota-dprdkota-malang-tersangka-suap-segera-disidang

Haboddin, M., \& Rahman, F. (2013). Gurita korupsi pemerintah daerah: Kaukaba Dipantara.

Hidayat, B. (2012). Seremonialisasi Proses Seleksi Kandidat Studi Pada Pemilihan Walikota dan Wakil Walikota Yogyakarta Tahun 2011 oleh Partai Demokrat. Universitas Gadjah Mada,

Katz, R. S., \& Crotty, W. J. (2006). Handbook of party politics: Sage.

KPU Kota Malang (2018). [Daftar Calon Tetap (DCT) Anggota Dewan Perwakilan Rakyat Daerah Kota Malang dalam Pemilihan Umum 2019].

Lundell, K. (2004). Determinants of candidate selection: The degree of centralization in comparative perspective. Party politics, 10(1), 25-47.

Rahat, G. (2009). Which Candidate Selection Method is the Most Democratic? 1. Government and Opposition, 44(1), 68-90.

Setyawan, F. A. (2018). KPK Tetapkan 22 Anggota DPRD Kota Malang Tersangka Suap. Retrieved from https://www.cnnindonesia.com/nasional/20180903174007-12327262/kpk-tetapkan-22-anggota-dprd-kota-malang-tersangka-suap

Yuwanto, Y. (2018). Parlemen dan Demokratisasi: Peran Dewan Perwakilan Rakyat dalam Transisi Demokrasi di Indonesia. Jurnal Ilmiah IImu Pemerintahan, 2(2), 43-50.

Zazili, A. (2016). Pengakuan Negara terhadap Hak-Hak Politik (Right to Vote) Masyarakat Adat dalam Pelaksanaan Pemilu (Studi Putusan Mahkamah Konstitusi No. 4781/Phpu. A-Vii/2009). Jurnal Konstitusi, 9(1), 135-162.

\section{Daftar Informan}

Maryadi, Mantan Ketua KPPS 10 Kelurahan Tasikmadu, Kecamatan Lowokwaru Kota Malang Pemilu 2019, 12 November 2019, pukul 09.43 WIB

Dwi Astutik, Pengurus DPD Partai Gerindra Kota Malang, 20 NOvember 2019, pukul 13.45 WIB.

M. Fachrudin, Koordinator Malang Corruption Watch (MCW) Malang, 27 November 2019, pukul 10.35 WIB

\section{Tentang Penulis}

Hadityo Anugrah Allahi merupakan mahasiswa pada Program Studi Ilmu Pemerintahan FISIP Universitas Brawijaya Malang.

Fathur Rahman adalah Pengajar pada Program Studi Ilmu Pemerintahan, Fakultas IImu Sosial dan IImu Politik, Universitas Brawijaya Malang. Penulis memiliki area riset seputar tema anti-korupsi, tata keuangan daerah, birokrasi pemerintahan. 